\title{
Erratum to: Malaysian Students' Performance in Mathematics Literacy in PISA from Gender and Socioeconomic Status Perspectives
}

\author{
Lei Mee Thien ${ }^{1}$
}

Published online: 2 June 2016

(C) De La Salle University 2016

\section{Erratum to: Asia-Pacific Edu Res DOI 10.1007/s40299-016-0295-0}

In the original publication of the article, there is a mistake in the 5th paragraph of the Introduction section.
"Malaysia was ranked as 74 ad 65 in PISA 2009+ edition and PISA 2012, respectively which is in the bottom third, and below the OECD average in the mathematics, science and reading literacies" should be written as:

"Malaysia was ranked in the bottom third out of 74 and 65 countries participated in PISA 2009+ edition and PISA 2012 respectively, and below the OECD average in the mathematics, science and reading literacies".

The online version of the original article can be found under doi: 10.1007/s40299-016-0295-0.

Lei Mee Thien

thienleimee@gmail.com

1 Research and Development Division, SEAMEO Regional Centre for Education in Science and Mathematics, 11700 Gelugor, Penang, Malaysia 